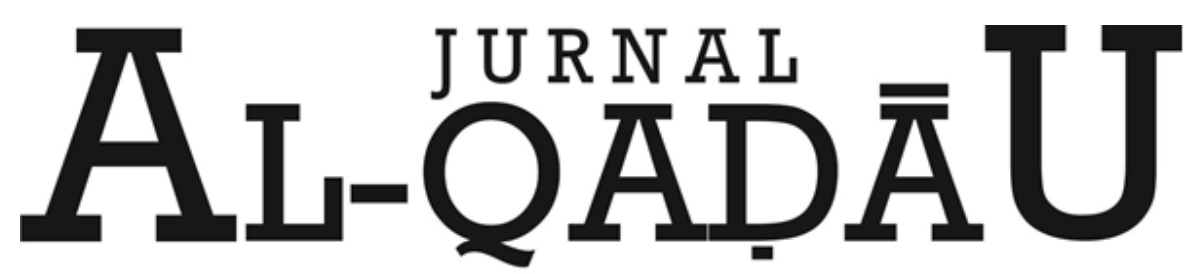

PERADILAN dan HUKUM KELUARGA ISLAM

\title{
Pandangan Hukum Islam terhadap Perkawinan Dibawah Tangan
}

Islamic Legal Views to The Marriage Under Legal Authorization

Nur Aisyah

Dosen Fakultas Syariah dan Hukum UIN Alauddin Makassar

Email: aisyahuin@gmail.com

\begin{tabular}{|c|c|}
\hline $\begin{array}{c}\text { Info } \\
\text { Artikel }\end{array}$ & Abstract \\
\hline $\begin{array}{l}\text { Diterima } \\
18 \\
\text { September } \\
2018\end{array}$ & $\begin{array}{l}\text { Pernikahan adalah hubungan lahir bathin antara laki-laki dan perempuan. } \\
\text { Sebagaimana halnya dengan semua bentuk perjanjian di sebuah negara } \\
\text { Hukum seperti Indonesia perkawinan tentu mempunyai aturan-aturan } \\
\text { yang harus dipahami dan dipatuhi oleh masyarakat yang hendak } \\
\text { melaksanakan perkawinan beserta hal-hal yang menyangkut dengannya. } \\
\text { Perkawinan dibawah tangan merupakan suatu perkawinan yang syarat } \\
\text { dan rukunnya terpenuhi, namun tidak tercatat atau tidak terdaftar di } \\
\text { Kantor Urusan Agama (KUA) dan tidak dihadiri oleh pejabat yang } \\
\text { berwenang. Meski sah menurut agama, namun perkawinan di bawah } \\
\text { tangan tidak berkah dan luput dari perlindungan hukum yang berwenang } \\
\text { serta perkawinan di bawah tangan tidak mempunyai kekuatan hukum } \\
\text { tetap. }\end{array}$ \\
\hline
\end{tabular}

2018

Kata kunci : Pernikahan Dibawah Tangan

Revisi II

15

Nopember

2018

Disetujui

19

Desember

2018
Marriage is a relationship of the birth of a man between men and women. As with any form of agreement in a state of Law such as Indonesia marriage certainly has the rules that must be understood and adhered to by the people who want to conduct marriage and things related to it. Marriage under the hands of a marriage is a requirement of marriage and conditions fulfilled, but not registered or not registered in the Office of Religious Affairs (KUA) and not attended by the authorities. Although legitimate in religion, however, the marriage is under the legitimation of no blessings and is escaped from the legal protection of the lawful and under-married marriage has no permanent legal force.

Keywords: Marriage, under legal authorization 
Nur Aisyah

\section{A. PENDAHULUAN}

Nikah adalah salah satu asas pokok hidup yang pertama dalam pergaulan suatu masyarakat yang sempurna, bukan saja perkawinan itu satu jalan yang amat mulia untuk mengatur kehidupan rumah tangga dan keturunan, tetapi perkawinan itu dapat dipandang sebagai satu jalam menuju pintu perkenalan antara satu kaum dengan yang lain. Suatu perkawinan itu akan menjadi jalan buat menyampaikan kepada bertolongtolongan antara satu dengan yang lainnya, sebagaimana hadis Nabi saw. yang memerintahkan kita untuk melaksanakan perkawinan.

$$
\text { النكاح سنتى فمن رغب عنه فليس منى (رو اه البخر ى) }
$$

Artinya:

Pernikahan adalah sunnahku, barang siapa yang tidak ingin menikah, maka ia bukan dari golonganku ummatku. HR. Bukhari. ${ }^{1}$

Demikian sabda Rasulullah saw yang menganjurkan kepada ummatnya untuk melakukan sunnah yakni pernikahan. Pernikahan sesungguhnya adalah sifat manusiawi. Dalam aturan Islam yang begitu kompleks mendeskripsikan tentang pernikahan. Mulai dari tata cara meminang sampai kepada terbentuknya keluarga yang sakinah. Bagi Islam tidak ada sesuatu yang sukar untuk dilakukan karena ajaran agama Islam itu mudah Termasuk pernikahan.

Pernikahan adalah hubungan lahir bathin antara laki-laki dan perempuan. Sebagaimana halnya dengan semua bentuk perjanjian di sebuah negara Hukum seperti Indonesia perkawinan tentu mempunyai aturan-aturan yang harus dipahami dan dipatuhi oleh masyarakat yang hendak melaksanakan perkawinan beserta hal-hal yang menyangkut dengannya, seperti rukun dan syarat perkawinan untuk melaksanakan perkawinan harus ada : calon suami,calon istri, wali nikah, dua orang saksi dan ijab kabul.

Adapun badan yang berwenang dalam hal terjadinya perkawinan adalah sebuah lembaga yang dibentuk oleh negara yaitu Kantor Urusan Agama dalam hal ini adalah Pegawai Pencatat Nikah (PPN) di bawah struktur Kementerian Agama. Lembaga lain yang ada kaitannya dengan pernikahan dan hal yang menyangkut dengannya misalnya perceraian serta pembagian harta gonogini adalah lembaga Pengadilan Agama.

Di Indonesia sendiri mempunyai beberapa aturan tentang perkawinan. Kompilasi Hukum Islam (KHI) merupakan salah satu Hukum yang mengatur tentang perkawinan yang mendapat justifikasi oleh pemerintah dengan dikeluarkannya Inpres Nomor 1 Tahun 1991. UU Nomor 7 Tahun 1989 serta masih banyak perundangundangan yang mengatur tentang perkawinan bagi umat muslim. ${ }^{2}$

Namun pada kenyataannya ada sebagian kecil masyarakat yang ternyata tidak memahami perundang-undangan tersebut. Mereka lebih senang dan bahkan menganggap sudah cukup apabila telah memenuhi persyaratan Agama dan adat. Maka ketika mereka ingin melaksanakan proses pernikahan, mereka tidak merasa perlu untuk

\footnotetext{
${ }^{1}$ Muhammad Nashiruddin Alalbani, hadis Shahih Bukhari, no. Hadis 974, h. 347

${ }^{2}$ Marzuki Wahid dan Rumadi, Fiqh Mazhab Negara: Kritik atas Politik Hukum Islam di Indonesia (Cet. I; Yogyakarta: LKIS, 2001), h. 21
} 
Nur Aisyah

berhubungan dengan lembaga-lembaga yang telah ditunjuk oleh pemerintah yang berwenang dalam hal ini adalah Kantor Urusan Agama -yang selanjutnya disebut KUA. Perkawinan mereka tidak tercatat di KUA. Sehingga perkawinan mereka dianggap tidak sah menurut aturan negara, meskipun bagi mereka sudah cukup ketika sudah disahkan oleh adat maupun Agama.

Pandangan seperti ini banyak ditemukan di Indonesia, bahkan terjadi hampir di setiap daerah. Perspektif seperti ini (cukup dengan aturan Agama dan adat) juga tidak sepenuhnya betul, karena kita hidup di wilayah negara Hukum yang punya aturan-aturan. Olehnya itu wajib bagi setiap warga negara mematuhi aturan-aturan yang telah ditetapkan oleh negara untuk ketertiban masyarakat itu sendiri.

Berdasarkan latar belakang di atas, maka persoalan yang menjadi kajian utama dalam penelitian ini yaitu bagaimana pandangan hukum Islam terhadap perkawinan dibawah tangan.

\section{B. METODE PENELITIAN}

Jenis penelitian ini merupakan library research (penelitian pustaka), yakni menelaah berbagai referensi yang relevan dengan masalah yang diteliti, menggunakan pendekatan yuridis dan historis.

Metode pengumpulan bersumber dari : 1. Data primer, yaitu data yang diperoleh dari berbagai literatur yang terkait dengan permasalahan. 2. Data sekunder, yaitu data yang diperoleh dari berbagai literatur, peraturan perundang-undangan, pendapat para ahli hukum, dokumen serta tulisan lain yang terkait materi yang dibahas sebagai penunjang.

Data yang berhasil diperoleh atau yang berhasil dikumpulkan selama proses penelitian baik itu data primer dan sekunder dianalisis secara kualitatif kemudian disajikan secara deskriptif yaitu, menguraikan, menggambarkan, dan menjelaskan sesuai dengan permasalahan yang erat kaitannya dengan penelitian ini

\section{PEMBAHASAN}

\section{Pengertian Kawin di Bawah Tangan}

Dalam Kamus Bahasa Indonesia, diterangkan bahwa kawin di bawah tangan merupakan sebuah perkawinan yang tidak dicatat pada lembaga negara yang berwenang. ${ }^{3}$ Yaitu suatu bentuk perkawinan yang telah merupakan bentuk perkawinan masa kini yang timbul dan berkembang pada sebagaian masyarakat Islam Indonesia. Mereka berusaha menghindari diri dari sistem dan cara pengaturan pekasanaan perkawinan menurut Undang-undang No. 1 tahun 1974 yang birokratis dan berbelitbelit serta lama pengurusannya. Untuk itu mereka menempuh cara sendiri yang tidak bertentangan dengan hukum Islam. Dalam ilmu hukum cara seperti itu dikenal dengan istilah "penyelundupan hukum", yaitu suatu cara menghindari diri dari persyaratan hukum yang ditentukan oleh Undang-undang dan peraturan yang berlaku dengan tujuan perbuatan yang bersangkutan, dapat menghindarkan suatu akibat hukum yang

\footnotetext{
${ }^{3}$ Departemen Pendidikan dan Kebudayaan, Kamus Besar Bahasa Indonesia (Cet. 1; Jakarta: Balai Pustaka, 1989), h. 131.
} 
Nur Aisyah

dikehendaki. ${ }^{4}$ Dalam hal ini yang menjadi lembaga negara yang khusus menangani pencatatan pernikahan adalah KUA. Dan yang khusus membidangi pencatatan adalah Pegawai Pencatat Nikah (PPN).

Menurut pasal 2 Bab II Kompilasi Hukum Islam (KHI), perkawinan menurut hukum Islam adalah pernikahan, yaitu akad yang sangat kuat atau mitsaqan ghalidzan untuk mentaati perintah Allah dan melaksanakannya merupakan ibadah. ${ }^{5}$

Pasal 4 KHI disebutkan, perkawinan adalah sah, apabila dilakukan menurut hukum Islam sesuai dengan pasal 2 ayat (1) Undang-undang No. 1 tahun 1974 tentang perkawinan dan Tata cara perkawinan menurut PP No. 9 Tahun $1975 .{ }^{6}$

Pasal 2 ayat 2 Undang-undang No. 1 Tahun 1974 tentang perkawinan menyebutkan bahwa, "Tiap-tiap perkawinan dicatat menurut peraturan perundangundangan yang berlaku". ${ }^{7}$ Kemudian pasal tersebut diatas diperjelas dengan adanya Bab 2 PP No. 9 Tahun 1975 yang menyebutkan bahwa," sebuah perkawinan baru dianggap memiliki kekuatan Hukum dihadapan undang-undang jika dilaksanakan menurut aturan agama dan telah dicatatkan oleh pegawai pencatat pernikahan yang ditentukan undang-undang". Aturan ini yang menimbulkan istilah perkawinan dibawah tangan, yaitu perkawinan yang tidak tercatat.

Dan kebalikan dari kedua aturan negara ini adalah perkawinan di bawah tangan, yang tidak terdaftar baik pada KUA ataupun Kantor Catatan Sipil. Perkawinan seperti inilah yang hendak dicegah atau diminimalisir karena tidak sesuai dengan aturan yang berlaku. Dalam Hukum di Indonesia, semua pernikahan harus didaftarkan di KUA. Sehingga apabila dikemudian hari terdapat hal-hal yang berkaitan dengan kebutuhan keluarga dapat dengan mudah mendapat pelayanan, karena memang sudah terdaftar.

Misalnya ketika sebuah pasangan ingin melakukan perceraian di Pengadilan Agama. Pendaftaran mereka tidak bisa diterima karena pernikahannya juga tidak terdaftar secara hukum.

Perkawinan dibawah tangan merupakan suatu perkawinan yang syarat dan rukunnya terpenuhi, namun tidak tercatat atau tidak terdaftar di Kantor Urusan Agama (KUA) dan tidak dihadiri oleh pejabat yang berwenang. Meski sah menurut agama, namun perkawinan di bawah tangan tidak berkah dan luput dari perlindungan Hukum yang berwenang serta perkawinan dibawah tangan tidak mempunyai kekuatan hukum tetap.

Setiap warga negara hendaknya melaksanakan setiap peraturan yang telah ditetapkan oleh pemerintah, sebab semua peraturan pada hakekatnya adalah bertujuan untuk kepentingan masyarakat, demikian juga dalam hal perkawinan.

Dengan melihat pasal 2 ayat 1 Undang-undang No. 1 Tahun 1974 yang menyatakan perkawinan itu sah apabila dilakukan menurut hukum masing-masing agamanya dan kepercayaannya itu. Maka, perkawinan di bawah tangan merupakan perkawinan yang sah menurut Undang-undang No. 1 Tahun 1974 dan sah menurut

${ }^{4}$ Gouw. G. Siong S. Hukum Perdata Internasional Indonesia ( Cet. IV; Jakarta: Kinta, 1964), h.

${ }^{5}$ Undang-Undang Peradilan Agama: UU RI Nomor 50 Tahun 2009 dan Kompilasi Hukum Islam (KHI) Bab 2 Pasal 2 (Pena Pustaka: Yogyakarta), h. 140.

${ }^{6}$ Undang-Undang Peradilan Agama: UU RI Nomor 50 Tahun 2009 dan Kompilasi Hukum Islam (KHI) Bab 2 Pasal 4 (Pena Pustaka: Yogyakarta), h. 140

${ }^{7}$ Republik Indonesia, Undang-undang Nomor 1 tahun 1974 Pasal 2 ayat (2) 
agama dengan terpenuhinya syaratdan rukun nikah itu. Sehingga banyak pendapat ahli Hukum dan sarjana Hukum bahwa perkawinan dibawah tangan adalah sah hanya kurang dalam pencatatan perkawinan atau syarat administratif saja. Tetapi bila melihat dari pasal 2 ayat 2 yang harus dibaca sebagai suatu kesatuan, artinya perkawinan yang sah adalah yang dilakukan berdasarkan agama dan kepercayaan itu dan harus dicatatkan sebagaimana diatur pasal $100 \mathrm{KUH}$ perdata yang menyatakan bahwa," Adanya suatu perkawinan tidak dapat dibuktikan dengan cara lain daripada dengan akta pelaksanaan perkawinan itu yang didaftarkan dalam daftar-daftar catatan sipil. Sehingga, akta perkawinan merupakan bukti satu-sat unya adanya suatu perkawinan.

Pada dasarnya, pencatatan nikah tidak disyariatkan dalam agama Islam. Namun, dilihat dari segi manfaatnya, pencatatan nikah sangat diperlukan. Berdasarkan realitas, bahwa suatu perkawinan tidak selalu langgeng, tidak sedikit terjadi perceraian yang penyelesaiannya berakhir di Pengadilan. Apabila perkawinan itu terdaftar di Kantor Urusan Agama (KUA) dan di samping itu pula mendapat akta nikah, maka untuk penyelesaian perceraian itu lebih mudah mengurusnya. Berbeda apabila suatu perkawinan tidak tercatat atau disebut perkawinan di bawah tangan dan tidak ada akta nikah, maka pengadilan agama tidak mau mengurusinya. Karena perkawinan itu dianggap tidak pernah terjadi. Orang yang melakukan perkawinan dibawah tangan, mereka hidup sebagai suami istri tanpa mempunyai kutipan akta nikah, yang pelaksanaannya itu dilaksanakan oleh pemuka agama di tempat perkawinan itu dilaksanakan.

Pencatatan perkawinan itu bertujuan untuk ketertiban perkawinan dalam masyarakat, ini merupakan suatu upaya yang diatur melalui perundang-undangan, untuk melindungi martabak dan kesucian perkawinan, dan lebih khusus bagi perempuan dalam kehidupan rumah tangga. Melalui pencatatan perkawinan yang dibuktikan dengan akta nikah yang masing-masing suami istri mendapat salinannya, apabila terjadi perselisihan atau percekcokan di antara mereka, atau salah satu di antara mereka tidak bertanggung jawab, maka yang lain dapat melakukan upaya Hukum guna mempertahankan atau memperoleh hak-hak masing-masing. Karena adanya akta tersebut, suami istri memiliki bukti otentik atas perbuatan Hukum yang telah mereka lakukan. Sahnya perkawinan bagi orang Islam di Indonesia, menurut Pasal 2 RUU Perkawinan tahun 1973, ditentukan berdasarkan "pencatatan perkawinan" sebagai unsur penentu. Hukum agama (Islam) dapat di berlakukan sepanjang tidak bertentangan dengan undang-undang ini yang berfungsi sebagai pelengkap, bukan penentu. RUU perkawinan Tahun 1973 merumuskan sahnya perkawinan dalam pasal 2 ayat (1) sebagai berikut:

"perkawinan adalah sah apabila dilakukan dihadapan pegawai pencatat perkawinan, dicatatkan dalam daftar pencatat perkawinan oleh pegawai tersebut, dan dilangsungkan menurut ketentuan undang-undang ini dan/ atau ketentuan Hukum perkawinan pihak-pihak yang melakukan perkawinan, sepanjang tidak bertentangan dengan undang-undang ini”.

Namun, pada kenyataannya masih terdapat masyarakat yang perkawinannya dilaksanakan tanpa sepengetahuan pencatat nikah. Adakalanya orang tua yang menganggap dirinya seorang kiyai atau pemuka agama, merasa bahwa tanpa kehadiran aparat yang berwenang juga sudah sah menurut Hukum agama Islam serta mereka menganggap hal tersebut hanyalah sifatnya administratif saja. Di beberapa media yang 
Nur Aisyah

mengimformasikan tentang perkawinan di bawah tangan di perbolehkan dan mereka menganggap bahwa perkawinan tersebut sah. Sementara itu jika dilihat dari perspektif Hukum pemerintahan dan norma sosial, perkawinan di bawah tangan adalah perkawinan yang menyimpang karena tidak tercatat di Kantor Urusan Agama (KUA) sebagai intansi yang berwenang sehingga tidak mempunyai kekuatan Hukum.

Dari berbagai penjelasan di atas, maka dapat ditarik kesimpulan bahwa perkawinan di bawah tangan ialah akad nikah antara seorang laki-laki dengan seorang perempuan yang pelaksanaannya hanya didasarkan pada ketentuan-ketentuan dalam Hukum agama Islam saja tanpa memperhatikan ketentuan-ketentuan dalam undangundang No. 1 Tahun 1974 Tentan perkawinan dan PP No. 9 Tahun 1975 Bab II tentang pencatatan perkawinan.

\section{Alasan-alasan Kawin di Bawah Tangan}

Secara umum tujuan dari perkawinan atau mengawini seseorang menurut ajaran Islam telah diatur, yakni untuk mendapatkan keturunan yang bertaqwa kepada Allah dan hidup secara mawaddah wa rahmah.

Dalam Islam, terdapat Hukum bagi mukallaf. Hal ini juga terkait dengan pernikahan. Wajib, bila seorang laki-laki sudah mapan dari segi ekonomi dan psikologi, dan apabila ia tidak menikah akan menimbulkan hal negatif bagi dirinya. Sunat, jika seorang laki-laki sudah mampu lahir dan batin tapi belum sampai pada tahap hiper, dan apabila ia tidak menikah tidak mendatangkan mudarat baginya. Haram, bila seorang laki-laki ingin beristri tetapi ia hanya berniat untuk memberikan kemudaratan kepada istrinya, meskipun ia sudah siap lahir dan batin terlebih lagi kalau ia tidak siap.

Karena menikah merupakan ajaran Islam, maka hal tersebut merupakan kewajiban yang mempunyai landasan formal syariat Islam. Dan Nabi waktu memerintahkan menikah kepada umatnya itu berada dalam negara yang Islami, yang beliau pimpin sendiri.

Hal ini berbeda ketika subjek yang ingin melakukan pernikahan berada dalam sebuah negara yang menganut paham demokrasi. Di mana Hukum yang berlaku adalah Hukum negara yang telah diundangkan. Meskipun sebenarnya Hukum tersebut, tetap mengakomodir sistem Hukum yang telah berlaku dalam masyarakat negara. Sistem Hukum yang berlaku di Indonesia sebelum diundangkan adalah sistem Hukum adat dan sistem Hukum Islam.

Jika demikian permasalahannya, maka orang yang ingin menikah harus mengikuti aturan-aturan negara. Aturan negara yang dimaksud adalah setiap pernikahan harus dicatat oleh Pegawai Pencatat Nikah yang bernaung di bawah KUA.

Persoalannya sebenarnya mudah, hanya mendaftar. Namun, sebagian masyarakat kita belum menyadari sepenuhnya pentingnya pencatatan pernikahan yang terjadi antara mereka. Pernikahan di bawah tangan seperti ini sering terjadi di kalangan selebritis. Maksud mereka melakukan hal tersebut bukan karena menganggap hal pendaftaran itu susah, tetapi lebih karena persoalan popularitasnya sebagai selebritis akan tereduksi.

Hal ini berbeda dengan pemahaman masyarakat biasa. Masyarakat biasa berpendapat pernikahan mereka jadi berbelit-belit. Maka cukuplah memenuhi rukun dan syarat nikah, sudah dianggap selesai. Pepatah klasik mengatakan bahwa ada asap menunjukkan adanya api, yaitu terjadinya sesuatu karena ada yang menjadikannya. 
Nur Aisyah

Adanya asumsi bahwa perkawinan di bawah tangan itu sah menurut Hukum Islam namun hanya kurang dari segi administratif, tingginya uang belanja yang ditetapkan pihak perempuan, dan adanya masyarakat yang masih awam dan berpendidikan rendah yang takut untuk berhadapan dengan pejabat pemerintah sehingga lebih memilih melaksanakan perkawinan dihadapan pemuka agama saja. Dari berbagai indikator-indikator tersebut kita mendapat gambaran bahwa implementasi undang-undang No. 1 Tahun 1974 belum maksimal khususnya pasal 2 ayat 2 yang menyatakan bahwa tiap-tiap perkawinan dicatat menurut perundang-undangan yang berlaku.

\section{Dampak yang Ditimbulkan Kawin di Bawah Tangan dalam Masyarakat}

Segala sesuatu yang terjadi pasti ada penyebabnya dan akibat yang ditimbulkan. Begitu pula dengan kawin di bawah tangan, akan menghasilkan sebuah dampak. Dampak yang dapat dirasakan oleh subjek yang melakukan kawin di bawah tangan. Maupun dampak yang timbulkan kepada masyarakat di sekitarnya.

Akibat Hukum perkawinan tersebut berdampak sangat merugikan bagi istri dan perempuan umumnya, baik secara Hukum maupun sosial, serta bagi anak yang dilahirkan di antaranya:

\section{Secara Hukum}

Perempuan tidak dianggap istri sah. Ia tidak berhak atas nafkah dan warisan dari suami jika ditinggal meninggal dunia. Selain itu sang istri tidak berhak atas harta gono-gini jika terjadi perpisahan, karena secara Hukum perkawinan tersebut dianggap tidak pernah terjadi.

2. Secara Sosial,

Istri akan sulit bersosialisasi karena perempuan yang melakukan perkawinan di bawah tangan, siring dianggap tinggal serumah dengan laki-laki tanpa ikatan perkawinan atau dianggap istri simpanan.

Tidak sahnya perkawinan di bawah tangan menurut Hukum negara, memiliki dampak negatif bagi status anak yang dilahirkan di mata Hukum. Status anak yang dilahirkan dianggap anak tidak sah. Konsekuensinya, anak hanya mempunyai hubungan perdata dengan ibu dan keluarga ibu. Keterangan berupa status sebagai anak di luar nikah dan tidak tercamtumnya nama sih ayah, akan berdampak sangat mendalam secara sosial dan psikologis bagi anak dan ibunya. Bisa saja, suatu waktu ayahnya menyangkal bahwa anak tersebut bukan anak kandungnya. Yang jelas-jelas sangat merugikan adalah, anak tidak berhak atas biaya kehidupan dan pendidikan, nafkah dan warisan dari ayahnya. Perkawinan di bawah tangan sangat berdampak menghawatirkan atau merugikan, kecuali jika kemudian perempuan tersebut melakukan perkawinan yang sah.

3. Bagi Anak Hasil Perkawinan Dibawah Tangan

Anak hasil perkawinan di bawah tangan dianggap anak tidak sah, apabila terjadi perkawinan sah anak hanya diakui. Sedangkan anak yang lahir di dalam perkawinan di bawah tangan dikatakan anak yang disahkan karena hanya ada pengakuan dari ayah anak tersebut dan harus disertai putusan Pengadilan. 
Nur Aisyah

Sedangkan terhadap laki-laki atau suami hampir tidak ada dampak menghawatirkan atau merugikan bagi diri laki-laki atau suami yang menikah bawah tangan dengan seorang perempuan. Yang terjadi justru menguntungkan, karena suami bebas untuk menikah lagi, karena perkawinan sebelumnya yang di bawah tangan dianggap tidak sah di mata Hukum. Suami bisa berkelit dan menghindar dari kewajibannya memberikan nafkah baik kepada istri maupun kepada anak-anaknya. Dan tidak dipusingkan dengan pembagian harta gono-gini, warisan dan lain-lain.

Hal ini dikarenakan perkawinan yang dilakukan adalah perkawinan di bawah tangan yang tidak tercatat dalam hukum negara. Selain itu anak yang lahir dari perkawinan bawah tangan biasanya juga mengalami kesulitan untuk mendapatkan akta kelahiran sebab orang tuanya tidak memiliki akta nikah. Jelas ini bertentangan dengan tujuan perkawinan menurut hukum Islam dimana perkawinan bertujuan untuk menjalankan perintah Allah swt. agar memperoleh keturunan yang sah dalam masyarakat dan membentuk keluarga yang sakinah, mawaddah dan warahma.

Hal-hal yang telah diuraikan di atas, juga berlaku bagi perkawinan yang dilakukan agama selain Islam dimana perkawinan adalah sah apabila telah dilaksanakan suatu pemberkatan atau ritual (upacara tertentu) menurut agama dan kepercayaan dari negara maka perkawinan tersebut perlu dicatatkan di kantor catatan sipil. Bagi agama selain Islam, akta nikah hanya dapat diperoleh dari kantor catatan sipil setelah pihak yang bersangkutan mencatatkan perkawinannya di lembaga pencatatan perkawinan tersebut.

Dengan dicatatnya perkawinan tersebut maka akan mendapat bukti otentik dari perkawinan yang telah dilakukannya sehingga apbila sewaktu-waktu terjadi hal-hal yang menyebabkan salah satu pihak (suami atau istri) melakukan suatu upaya hukum, maka perkara tersebut dapat segera dapat diajukan di Pengadilan negeri untuk mendapat kepastian Hukum.

Dari uraian di atas maka dapat disimpulkan bahwa perkawinan di bawah tangan jelas-jelas sangat merugikan baik bagi istri maupun anak yang dilahirkannya, karena perkawinan tersebut tidak tercatat di Kantor Urusan Agama maka perkawinan tersebut tidak dianggap tidak sah secara hukum dan tidak mempunyai kekuatan hukum tetap, sehingga sangat merugikan istri dan anak yang dilahirkan.

\section{Pandangan Hukum Islam tentang perkawinan di bawah tangan}

Istilah perkawinan di bawah tangan muncul setelah undang-undang No 1 tahun 1974 tentang perkawinan yang berlaku pada tanggal 1 oktober 1975. Perkawinan di bawah tangan pada dasarnya adalah kebalikan dari perkawinan yang dilakukan menurut Hukum, dan perkawinan menurut Hukum adalah perkawinan yang diatur dalam undang-undang perkawinan termasuk dalam hal pencatatan perkawinan. Dengan demikian perkawinan di bawah tangan merupakan perkawinan yang dilakukan tidak menurut hukum, dan nikah seperti itu dianggap sebagai perkawinan liar, sehingga tidak mempunyai akibat Hukum berupa pengakuan dan perlindungan hukum. Membahas masalah perkawinan di bawah tangan, itu tidak terlepas dari pencatatan perkawinan, sebagaimana perkawinan di bawah tangan merupakan perkawinan yang syarat dan rukunnya terpenuhi namun tidak tercatat atau tidak terdaftar di Kantor Urusan Agama. Pada mulanya syariat Islam, baik dalam al-Qur'an maupun sunnah tidak mengatur secara kongkrit tentang adanya pencatatan perkawinan. Namun, tuntutan 
perkembangan zaman dalam berbagai pertimbangan kemaslahatan, maka Hukum Islam di Indonesia mengaturnya.

Dalam beberapa literatur Hukum Islam memang tidak dikenal adanya istilah pencatatan dalam perkawinan. Sah dan tidaknya suatu perkawinan tidak digantungkan kepada ada atau tidaknya pencatatan, tapi diukur ada dan tidaknya syarat dan rukun nikah. Oleh karena itu muncul pertanyaan apakah karena masalah pencatatan perkawinan ini tidak dijelaskan dalam kitab-kitab fiqh sehingga pencatatan perkawinan menjadi suatu hal yang tidak perlu dilakukan? Dan bagaimana sebenarnya Islam memandang masalah pencatatan ini?

Secara tekstual memang tidak ada dalil, baik dari al-Qur' an maupun Hadis yang menyebutkan bahwa pencatatan perkawinan merupakan suatu ukuran keabsahan perkawinan. Namun bila dikaji lebih jauh ada riwayat hadist yang menyebutkan bahwa perkawinan harus diumumkan dan dibunyikan rebana agar banyak orang yang menyaksikannya. Hadist lain mengisahkan agar perkawinan dipestakan walau hanya menyembelih seekor kambing untuk makanan bagi yang hadir dalam pesta perkawinan. Hal ini dilakukan agar perkawinan yang dilaksanakan bisa diketahui oleh lain. Lebih banyak orang yang mengetahui peristiwa perkawinan seseorang, maka itu akan lebih baik lagi. Inilah yang kemudian menjadi isyarat bahwa pencatatan perkawinan menjadi sangat penting dan perlu dilakukan.

Lebih jauh dalam analisa Hukum Islam dapat dijelaskan bahwa tujuan syariat Islam (maqashid al syariah) adalah mendatangkan maslahat dan menghindarkan dari bahaya. Karena perkawinan yang dicatat pemerintah menimbulkan mudharat kepada istri, anak dan harta perkawinan /harta bersama, maka pencatatan perkawinan oleh pemerintah menurut Hukum Islam dipandang sebagai darurat. Ketentuan umum bagi sahnya perkawinan yang telah disebutkan di atas adalah hasil ijtihad karena tidak disebutkan secara rinci di dalam Al-qur'an dan Hadist. Hukum yang di tetapkan berdasarkan ijtihad dapat berubah sesuai kondisi selama perubahan Hukum itu untuk kemaslahatan dan tidak bertentangan dengan Al-qur'an dan hadis atau maqashid al syariah, berdasarkan kaidah fiqhiyah yang mengatakan bahwa Hukum dapat berubah disebabkan perubahan keadaan dan zaman. ${ }^{8}$

Harus dipertimbangkan bahwa perkembangan hukum itu sangat tergantung kepada perkembangan masyarakat, bahwa hukum akan selalu berubah sesuai dengan faktor-faktor yang mengubahnya.

Di samping kaidah tersebut di atas, ada satu teori hukum Islam yang bisa dijadikan dasar pijakan tentang perlunya pencatatan perkawinan ini yaitu teori mashlahah mursalah. Teori ini mengajarkan bahwa apa yang tidak diparintahkan secara tekstual dalam al-qur'an dan Hadis dapat dibuat suatu aturan berdasarkan nilai kemaslahatan dan sekaligus menghindari mudharat. Untuk menilai apakah suatu kegiatan yang Hukumnya akan ditetapkan itu mempunyai unsur maslahat atau tidak, menurut para ahli teori Hukum Islam, harus ada tiga kriteria, pertama: kemaslahatan itu bersifat universal; kedua: kemaslahatan itu bersifat pasti atau tidak bersifat hipotetif; dan ketiga: kemaslahatan itu bersifat esensial.

${ }^{8}$ Huzaimah Tahido Yanggo, Perkawinan yang tidak dicatat pemerintah: Pandangan Islam (Jakarta:2007) 
Nur Aisyah

Oleh karena itu berdasarkan uraian di atas dengan memperhatikan kaidahkaidah yang ada, penulis berpendapat bahwa demi ketertiban Hukum dimasyarakat dan mengingat manfaat yang didapat maka pencatatan perkawinan adalah suatu hal yang sangat urgen dan wajib untuk dicatatkan.

Dalam pandangan perundang-undangan di Indonesia, ada beberapa landasan Hukum yang mengatur pentingnya pencatatan perkawinan di antaranya adalah undangundang No 1 Tahun 1974 tentang perkawinan . dalam pasal 2 ayat (2) dikatakan bahwa tiap-tiap perkawinan dicatat menurut peraturan perundang-undangan yang berlaku. Peraturan merinci bahwa lembaga yang berwenang menangani perkawinan adalah kantor catatan sipil (KCS) bagi non Islam dan Kantor Urusan Agama (KUA) bagi penganut agama Islam.

Peraturan pemerintah No. 9 Tahun 1975 tentang peraturan pelaksanaan Undang-undang No. 1 Tahun 1974 tentang perkawinan mengatur tentang tata cara dan tata laksana perkawinan dan pencatatan perkawinan. Beberapa pasal yang dianggap penting untuk dikemukakan yaitu, pasal 2 PP No.9 Tahun 1975 ayat (1) yang menentukan pencatatan perkawinan bagi orang Islam dilakukan oleh pegawai pencatat nikah sebagaimana dimaksud dalam undang-undang No. 22 Tahun 1946 jo. Undangundang No. 32 Tahun $1954 .^{9}$

Ketentuan pencatatan perkawinan juga diamanatkan melalui intruksi Presiden No. 1 Tahun 1991 tentang kompilasi Hukum Islam (KHI) pasal 5 yang berbunyi:

1. Agar terjamin ketertiban perkawinan bagi masyarakat Islam, setiap perkawinan harus di catat.

2. Pencatatan perkawinan tersebut pada ayat (1) dilakukan oleh pegawai pencatat nikah sebagai mana diatur dalam undang-undang No. 22 Tahun 1946 jo. Undang-undang No. 32 Tahun 1954.

Adapun teknis pelaksanaannya, dijelaskan dalam pasal 6 yang menyebutkan:

1. Untuk memenuhi ketentuan dalam pasal 5, setiap perkawinan harus dilangsungkan dihadapan dan di bawah pengawasan pegawai pencatat nikah.

2. Perkawinan yang dilakukan di luar pengawasan pegawai pencatat nikah tidak mempunyai kekuatan hukum.

Dalam undang-undang No. 23 Tahun 2006 tentang administrasi kependudukan yang dikeluarkan pada tanggal 29 desember Tahun 2006 juga dijabarkan mengenai pencatatan perkawinan yaitu mengatur tata cara dan tata laksana pencatatan peristiwa penting atau pencatatan sipil yang dialami penduduk Republik Indonesia. Pencatatan perkawinan bagi penduduk yang beragama Islam, pasal 8 undang-undang No. 23 Tahun 2006 menentukan, bahwa kewajiban instansi pelaksana untuk pencatatan nikah, talak, cerai, dan rujuk bagi penduduk yang beragama Islam pada tingkat kecamatan dilakukan oleh pegawai pencatat pada KUA kecamatan.

Jadi dengan pencatatan perkawinan oleh pemerintah, selain peristiwa perkawinan di umumkan ke khalayak, pada hakekatnya juga memuat akibat dan konsekuensi Hukum, yakni kejelasan hak dan kewajiban bagi masing-masing pasangan, hak anak dan kewajiban orang tua terhadap anak, juga hak pasangan jika salah satunya

${ }^{9}$ Neng Djubaidah, Pencatatan Perkawinan \& Perkawinan tidak dicatat (Cet. 1; Jakarta: Sinar Grafika Offset, 2010), h. 217. 
meninggal. Intinya, tuntutan pencatatan perkawinan itu dilandasi oleh pertimbangan kemaslahatan atau manfaatnya bagi yang bersangkutan dan bagi yang berkaitan dengannya. Dalam bahasa administrasi, tujuan pencatatan perkawinan adalah untuk mewujudkan ketertiban perkawinan dalam masyarakat, dan itu merupakan suatu upaya yang diatur melalui perundang-undangan untuk melindungi martabat dan kesucian perkawinan, lebi khusus lagi untuk melindungi hak-hak perempuan dalam kehidupan rumah tangga. Dari berbagai penjelasan di atas maka penulis dapat menarik kesimpulan bahwa walaupun hukum Islam dan hukum positif berbeda dalam memandang keabsahan perkawinan, namun dari perbedaan tersebut dapat di ambil kesimpulan bahwa dalam kehidupan masyarakat yang kian maju dan modern, pencatatan perkawinan merupakan suatu hal yang sangat urgent mengingat kemaslahatan yang terkandung di dalamnya. Hukum Islam dan hukum positif dapat dijadikan sumber hukum yang saling melengkapi antara yang satu dengan yang lainnya sebab kedua aturan tersebut mempunyai tujuan hukum yang sama yaitu sama-sama berusaha menciptakan ketertiban hidup di tengah-tengah masyarakat.

\section{PENUTUP}

\section{Kesimpulan}

1. Pada mulanya syariat Islam, baik dalam al-Qur'an maupun sunnah tidak mengatur secara kongkrit tentang adanya pencatatan perkawinan. Namun, tuntutan perkembangan zaman dalam berbagai pertimbangan kemaslahatan, maka Hukum Islam di Indonesia mengaturnya. Karena perkawinan yang dicatat pemerintah menimbulkan mudharat kepada istri, anak dan harta perkawinan /harta bersama, maka pencatatan perkawinan oleh pemerintah menurut Hukum Islam dipandang sebagai darurat.

2. Ketentuan umum bagi sahnya perkawinan yang telah disebutkan di atas adalah hasil ijtihad karena tidak disebutkan secara rinci di dalam Al-qur'an dan Hadist. Hukum yang di tetapkan berdasarkan ijtihad dapat berubah sesuai kondisi selama perubahan Hukum itu untuk kemaslahatan dan tidak bertentangan dengan Al-qur'an dan hadis at au maqashid al syariah, berdasarkan kaidah fiqhiyah yang mengatakan bahwa Hukum

\section{Implikasi} dapat berubah disebabkan perubahan keadaan dan zaman.

1. Dalam melaksanakan pernikahan hendaknya pihak yang terkait mencatat pernikahan di KUA agar dapat diakui baik secara agama maupun negara. Sehingga tidak menimbulkan kerugian kepada pihak-pihak yang bersangkutan.

2. Pemerintah yang berwenang dalam hal tersebut hendaknya mensosialisasikan pandangan hukum Islam serta dampaknya perkawinan dibawah tangan kepada masyarakat. 
Nur Aisyah

\section{DAFTAR PUSTAKA}

Alalbani, Muhammad Nashiruddin. hadis Shahih Bukhariy, no. Hadis 974.

Departemen Pendidikan dan Kebudayaan, Kamus Besar Bahasa Indonesia. Cet. I; Jakarta: Balai Pustaka, 1989.

Djubaidah, Neng. Pencatatan Perkawinan \& Perkawinan tidak dicatat. Cet. 1; Jakarta: Sinar Grafika Offset, 2010.

Rumadi, Marzuki Wahid. Fiqh Mazhab Negara: Kritik atas Politik Hukum Islam di Indonesia. Cet. I; Yogyakarta: LKIS, 2001.

Siong S Gouw. G. Hukum Perdata Internasional Indonesia. Cet. IV; Jakarta: Kinta, 1964.

Undang-Undang Peradilan Agama: UU RI Nomor 50 Tahun 2009 dan Kompilasi Hukum Islam (KHI) Bab 2 Pasal 2. Pena Pustaka: Yogyakarta.

Undang-Undang Peradilan Agama: UU RI Nomor 50 Tahun 2009 dan Kompilasi Hukum Islam (KHI) Bab 2 Pasal 4. Pena Pustaka: Yogyakarta. Republik Indonesia, Undang-undang Nomor 1 tahun 1974 Pasal 2 ayat (2)

Yanggo, Huzaimah Tahido. Perkawinan yang tidak dicatat pemerintah: Pandangan Islam. Jakarta:2007. 